\title{
Ferrocene-bridged $\mathrm{Pd}-\mathrm{NCN}$ pincer complexes
}

\author{
Stefan Köcher ${ }^{\mathrm{a}}$, Gerard P.M. van Klink ${ }^{\mathrm{b}}$, Gerard van Koten ${ }^{\mathrm{b}}$, Heinrich Lang ${ }^{\mathrm{a}}{ }^{*}$ \\ ${ }^{a}$ Technische Universität Chemnitz, Fakultät für Naturwissenschaften, Institut für Chemie, Lehrstuhl Anorganische Chemie, Straße der Nationen 62, D- \\ 09111 Chemnitz, Germany \\ b Department of Metal-Mediated Synthesis, Utrecht University, Debye Institute, Padualaan 8, 3584 CH Utrecht, The Netherlands
}

Received 10 March 2003; received in revised form 30 June 2003; accepted 30 June 2003

Dedicated to Prof. E.O. Fischer on the occasion of his 85 th birthday

\begin{abstract}
The meta-diaminoaryl ferrocene $\mathrm{Fe}\left[\eta^{5}-\mathrm{C}_{5} \mathrm{H}_{4}(\mathrm{NCNH})\right]_{2}\left[\mathrm{NCNH}=1-\mathrm{C}_{6} \mathrm{H}_{3}\left(\mathrm{CH}_{2} \mathrm{NMe}_{2}\right)_{2}-3,5\right]$ (3) can be synthesised by the reaction of $\mathrm{Fe}\left[\eta^{5}-\mathrm{C}_{5} \mathrm{H}_{4}(\mathrm{ZnCl})\right]_{2}(\mathbf{1})$ with $\mathrm{I}-\mathrm{C}_{6} \mathrm{H}_{3}\left(\mathrm{CH}_{2} \mathrm{NMe}_{2}\right)_{2}-3,5$ (2) in a 1:2 molar ratio in the presence of catalytic amounts of $\left[\mathrm{Pd}\left(\mathrm{PPh}_{3}\right)_{2}\right]$. The two meta-dimaminoaryl NCNH pincer units in $\mathbf{3}$ can be used to assemble multimetallic complexes. Thus, $\mathbf{3}$ produces on reaction with ${ }^{\mathrm{t}} \mathrm{BuLi}$ and $\left(\mathrm{Me}_{2} \mathrm{~S}\right)_{2} \mathrm{PdCl}_{2}$ trimetallic $\mathrm{Fe}\left[\eta^{5}-\mathrm{C}_{5} \mathrm{H}_{4}(\mathrm{NCN}-4-\mathrm{PdCl})\right]_{2}\left\{\mathrm{NCN}=1-\mathrm{C}_{6} \mathrm{H}_{2}\left(\mathrm{CH}_{2} \mathrm{NMe}_{2}\right)_{2}-3,5\right\}$ (6) along with heterobimetallic $\mathrm{Fe}\left[\eta^{5}-\mathrm{C}_{5} \mathrm{H}_{4}(\mathrm{NCNH})\right]\left[\eta^{5}-\mathrm{C}_{5} \mathrm{H}_{4}(\mathrm{NCN}-4-\mathrm{PdCl})\right](5)$. Complex 6 contains two bis-ortho-chelated pincer $\mathrm{NCN}-\mathrm{PdCl}$ units, whereas 5 possesses one bis-ortho-chelated NCN pincer entity and one non-metallated NCNH moiety. Complex 6 is the first example in organometallic chemistry in which two bis-ortho-chelated diaminoaryl palladium units are bridged via the respective para $\mathrm{C}$-atoms spanned by a redox-active ferrocenyl building block.
\end{abstract}

(C) 2003 Elsevier B.V. All rights reserved.

Keywords: Ferrocene; NCN pincer; Palladium; Multimetallic; Cyclic voltammetry

\section{Introduction}

In addition to monoanionic diphosphino- and disulfido-aryl anions the organometallic chemistry of the related diaminoaryl ligand $\mathrm{NCN} \quad(\mathrm{NCN}=$ $\left.\left[\mathrm{C}_{6} \mathrm{H}_{3}\left(\mathrm{CH}_{2} \mathrm{NMe}_{2}\right)_{2}-2,6\right]^{-}\right)$has been investigated intensively $[1,2]$. In pincer halide transition metal complexes (structural type A molecule), for example, stable palladium-carbon bonds are present, due to the chelating effect of the monoanionic NCN ligand. [3] This opens the possibility to synthesize para-functionalised $\mathrm{Y}-$ NCN-MX complexes, which can be used as building blocks to prepare larger molecules. [4]

* Corresponding author. Tel.: +49-371-531-1200; fax: +49-371531-1833.

E-mail addresses: g.vankoten@chem.uu.nl (G. van Koten), heinrich.lang@chemie.tu-chemnitz.de (H. Lang).

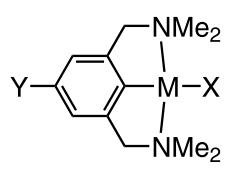

A

$$
\begin{aligned}
& \mathrm{M}=\mathrm{Ni}, \mathrm{Pd}, \mathrm{Pt} \\
& \mathrm{X}=\mathrm{Cl}, \mathrm{Br}, \mathrm{BF}_{4}, \mathrm{C} \equiv \mathrm{CFc}, \ldots \\
& \mathrm{Y}=\mathrm{H}, \mathrm{OH}, \mathrm{CO}_{2} \mathrm{H}, \mathrm{C} \equiv \mathrm{CH}, \ldots
\end{aligned}
$$

Such complexes can be used, for example, for creating materials with electronic conduction along $\pi$-conjugated organometallic chains [5] or for the synthesis of liquid crystalline materials. [6] The functionalities $\mathrm{X}$ or $\mathrm{Y}$ in molecules of structural type A allow the introduction of a second transition metal containing fragment (homoor heterobimetallic) in which the respective transition metals are connected via conjugated organic units. The synthesis of multimetallic assemblies is given by suitable modification of both $\mathrm{X}$ and $\mathrm{Y}$. While in the latter type of molecules the transition metals are spanned by $\pi$ - 


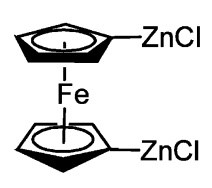

1

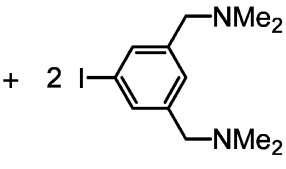

2

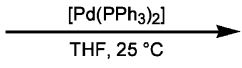

$\mathrm{THF}, 25^{\circ} \mathrm{C}$

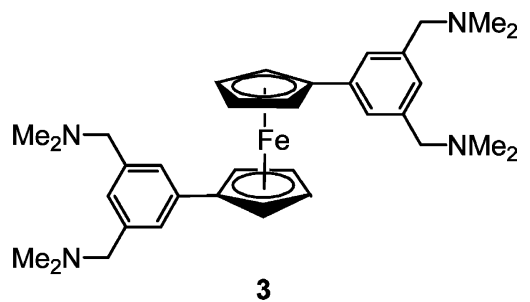

conjugated organic groups, to the best of our knowledge, nothing is known about such systems in which $\mathrm{X}$ or $\mathrm{Y}$ are redox-active organometallic bridging units.

We here report on the synthesis and subsequent palladation of the 1,1'-bis-NCNH-pincer functionalised ferrocene, $\quad \mathrm{Fe}\left[\eta^{5}-\mathrm{C}_{5} \mathrm{H}_{4}(\mathrm{NCNH})\right]_{2} \quad[\mathrm{NCNH}=1-$ $\left.\mathrm{C}_{6} \mathrm{H}_{3}\left(\mathrm{CH}_{2} \mathrm{NMe}_{2}\right)_{2}-3,5\right]$, to give novel trimetallic $\mathrm{Fe}\left[\eta^{5}-\right.$ $\left.\mathrm{C}_{5} \mathrm{H}_{4}(\mathrm{NCN}-4-\mathrm{PdCl})\right]_{2}$.

\section{Results and discussion}

The synthesis of $\mathrm{Fe}\left[\eta^{5}-\mathrm{C}_{5} \mathrm{H}_{4}(\mathrm{NCNH})\right]_{2}$ (3) was attempted using different methods. Aryl-aryl coupling reactions can successfully be achieved by the Suzuki reaction [7]. However, it appeared that the application of this type of reaction, using either $\mathrm{Fe}\left(\eta^{5}-\mathrm{C}_{5} \mathrm{H}_{4} \mathrm{I}\right)_{2}$ and $(\mathrm{HO})_{2} \mathrm{~B}\left[\mathrm{C}_{6} \mathrm{H}_{3}\left(\mathrm{CH}_{2} \mathrm{NMe}_{2}\right)_{2}-3,5\right]$ or $\mathrm{Fe}\left\{\eta^{5}-\right.$ $\left.\mathrm{C}_{5} \mathrm{H}_{4}\left[\mathrm{~B}(\mathrm{OH})_{2}\right]\right\}_{2}$ and $\mathrm{IC}_{6} \mathrm{H}_{3}\left(\mathrm{CH}_{2} \mathrm{NMe}_{2}\right)_{2}-3,5$ (2) as reactants, produced complex 3 in very low yield (5-9\%). A more suitable route for the synthesis of $\mathbf{3}$ involved the reaction of $\mathrm{Fe}\left[\eta^{5}-\mathrm{C}_{5} \mathrm{H}_{4}(\mathrm{ZnCl})\right]_{2}$ (1) [8] with two equivalents of $\mathrm{IC}_{6} \mathrm{H}_{3}\left(\mathrm{CH}_{2} \mathrm{NMe}_{2}\right)_{2}-3,5$ (2) in the presence of catalytic amounts of $\left[\mathrm{Pd}\left(\mathrm{PPh}_{3}\right)_{2}\right]$ in tetrahydrofuran at $25^{\circ} \mathrm{C}$ (Eq. (1)). Complex 3 was isolated in 39\% yield as a brown oil.

As complex 3 contains two NCNH pincer units, it should be possible to prepare heterobi- $(\mathrm{FeM})$ or trimetallic $\left(\mathrm{FeM}_{2}\right)$ species $(\mathrm{M}=$ Group-10 transition metal atom). This could be achieved in a two-step synthesis. Firstly, $\mathbf{3}$ was reacted with two equivalents of ${ }^{t} \mathrm{BuLi}$ at low temperature to the corresponding ferrocenyl bis(aryllithium) compound $\mathrm{Fe}\left[\eta^{5}-\mathrm{C}_{5} \mathrm{H}_{4}(\mathrm{NCN}-\mathrm{Li})\right]_{2}$ (Eq. (2)). Transmetallation of the latter dilithium derivative with $\left(\mathrm{Me}_{2} \mathrm{~S}\right)_{2} \mathrm{PdCl}_{2}$ gave the corresponding trimetallic compound $\mathrm{Fe}\left[\eta^{5}-\mathrm{C}_{5} \mathrm{H}_{4}(\mathrm{NCN}-\mathrm{PdCl})\right]_{2}$ (6) along with dimetallic $\mathrm{Fe}\left[\eta^{5}-\mathrm{C}_{5} \mathrm{H}_{4}(\mathrm{NCNH})\right]\left[\eta^{5}\right.$ $\left.\mathrm{C}_{5} \mathrm{H}_{4}(\mathrm{NCN}-\mathrm{PdCl})\right]$ (5) (Eq. (2)). The crude reaction product also contained traces of $\mathbf{3}$ and other yet unidentified products. Nevertheless, separation of $\mathbf{5}$ and $\mathbf{6}$ from such impurities and side products appeared of astonishing simplicity, because 3 could be removed by extraction of the reaction product with hexane. Subsequently, $\mathbf{5}$ could be isolated by extraction with diethyl ether and $\mathbf{6}$ with dichloromethane. After appropriate work-up, $\mathbf{3}$ was isolated pure as a brown oil, while $\mathbf{5}$ and 6 were obtained as orange solids.

The solubilities of $\mathbf{3 , 5}$ and $\mathbf{6}$ increase with increasing
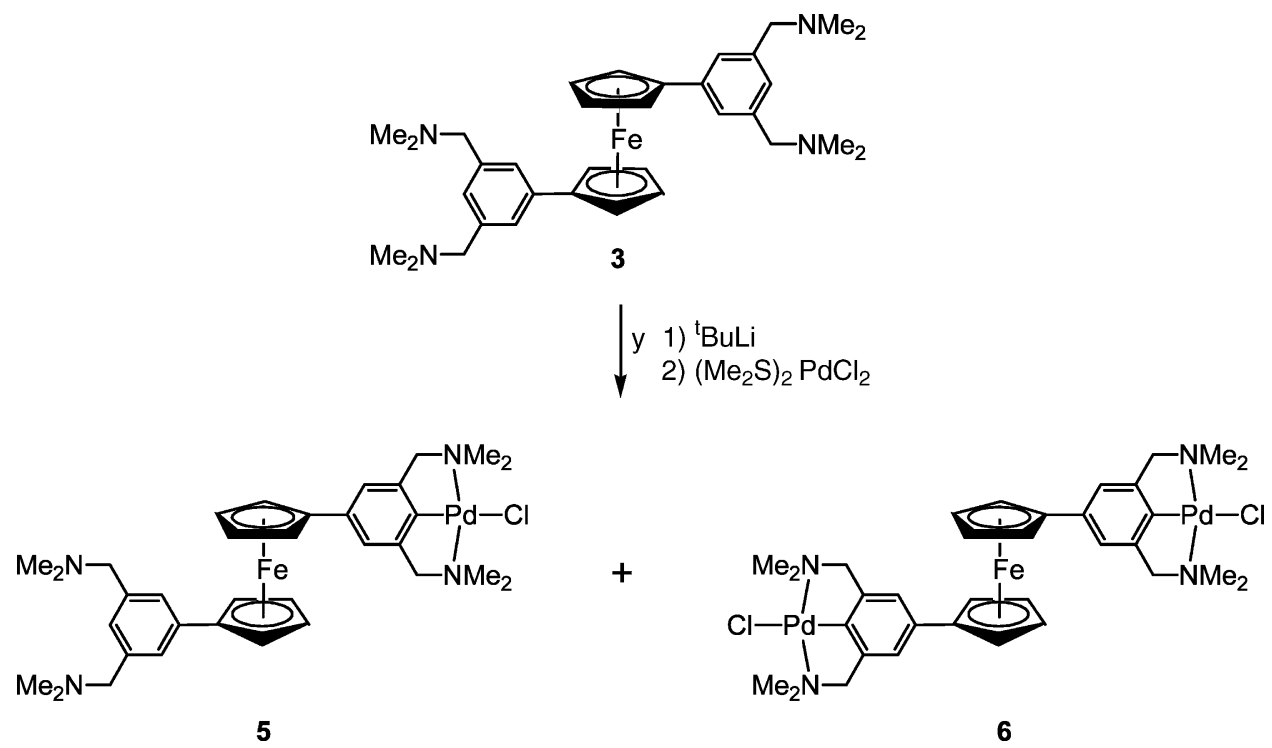


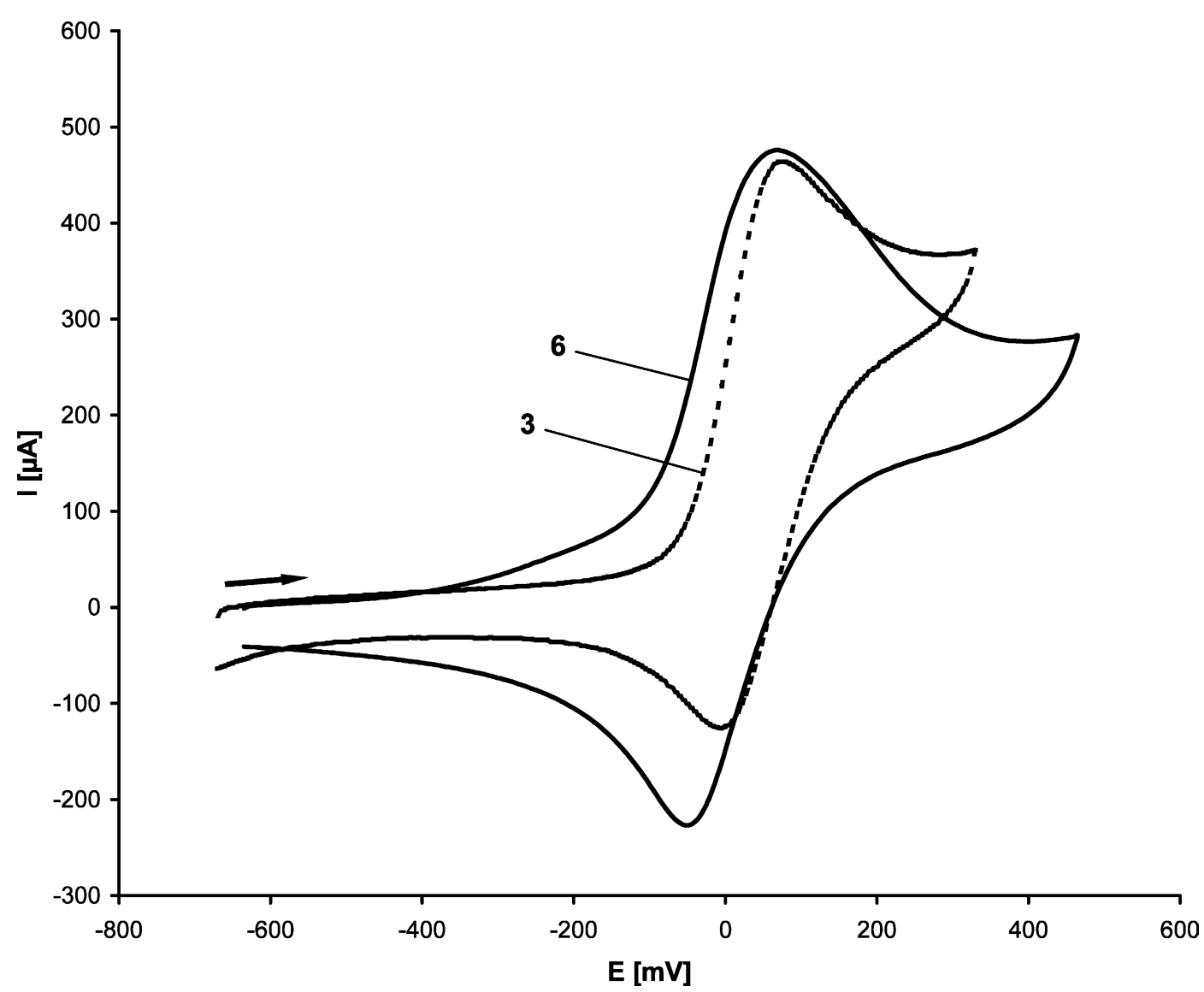

Fig. 1. Cyclic voltammograms of $\mathbf{3}$ (dotted line) and $\mathbf{6}$ (solid line) in acetonitrile solutions at $25^{\circ} \mathrm{C}$.

number of Pd centres. A similar behaviour is found in other multimetallic transition metal NCN pincer complexes. [2,3,9] Whereas $\mathbf{3}, \mathbf{5}$ and $\mathbf{6}$ are stable in an inert gas atmosphere over a long period of time it appeared that on exposure to air they slowly start to decompose. Notably the compounds with free NCN pincer units, i.e. non-coordinating $\mathrm{CH}_{2} \mathrm{NMe}_{2}$ substituents, are less stable than 6 in which both pincer units are cyclopalladated.

Complexes 3, 5 and 6 were fully characterized by ${ }^{1} \mathrm{H}$ and ${ }^{13} \mathrm{C}(1 \mathrm{H})$ spectroscopy. ESI-TOF (electrospray ionisation time-of-flight) studies and elemental analysis confirmed the proposed compositions.

As expected, the ${ }^{1} \mathrm{H}-\mathrm{NMR}$ spectrum of $\mathbf{3}, \mathbf{5}$ and $\mathbf{6}$ in $\mathrm{CDCl}_{3}$ showed $\mathrm{AA}^{\prime} \mathrm{BB}^{\prime}$ patterns for the cyclopentadienyl ring protons with coupling constants of $1.8 \mathrm{~Hz}$. Moreover, in $\mathbf{3}$ and $\mathbf{6}$ two pseudo-triplets between 4.1 and $4.5 \mathrm{ppm}$ are observed, while in $\mathbf{5}$ four cyclopentadienyl proton resonance signals appeared, due to lower symmetry, when compared with 3 and $\mathbf{6}$. The $\mathrm{CH}_{2}$ and $\mathrm{NMe}_{2}$ protons of the NCN ligands appear as singlets. Upon coordination of the nitrogen atoms to the $\mathrm{Pd}$ centres a significant shift of the $\mathrm{CH}_{2}$ and $\mathrm{NMe}_{2}$ resonances to lower field occurs $\left(\mathbf{3}, \mathbf{5}\right.$ and $\mathbf{6} ; \mathrm{NMe}_{2}$ : 2.25, 2.28/2.95 and 2.98; $\mathrm{CH}_{2}: 3.40,3.45 / 3.96$ and 4.01 ppm). The presence of the 4-PdCl units in 5 and $\mathbf{6}$ are obvious from the absence of the $4-\mathrm{CH}$ proton in the 1-
$\mathrm{C}_{6} \mathrm{H}_{2}\left(\mathrm{CH}_{2} \mathrm{NMe}_{2}\right)_{2}-3,5$ fragments of 3 and 5. Accordingly, $\mathrm{C}(4)$ in the ${ }^{13} \mathrm{C}\left\{{ }^{1} \mathrm{H}\right\}$-NMR spectra has shifted to lower field (3, 5 and 6; $\operatorname{ArC}(4)$ 127.7, 152.4 and 154.4 ppm). Similar downfield shifts are also typical for the $\mathrm{CH}_{2}$ and $\mathrm{NMe}_{2}$ carbon atoms going from 3 to 5 to $\mathbf{6}$ (Section 3). All other resonance signals appear as wellresolved signals in the expected region.

Cyclic voltammetric studies were carried out for complexes 3 and $\mathbf{6}$ in acetonitrile solutions at $25^{\circ} \mathrm{C}$. The obtained cyclic voltammograms are depicted in Fig. 1.

It was found that the $\mathrm{Fe}(\mathrm{II}) / \mathrm{Fe}(\mathrm{III})$ oxidation $(E=+$ $0.03 \mathrm{~V}, \Delta E=80 \mathrm{mV}$ ) in 3 is reversible (Fig. 1), and is, as compared to the $\mathrm{FcH} / \mathrm{FcH}^{+}$redox-couple, shifted to a more positive value. This displacement can be interpreted by means of a stronger electron withdrawing group present in 3 than in $\mathrm{FcH}$, taken as standard. [10]

The cyclic voltammogram of $\mathbf{6}$ also exhibits a reversible $\mathrm{Fe}(\mathrm{II}) / \mathrm{Fe}(\mathrm{III})$ redox couple at $E=-0.03 \mathrm{~V}$ $(\Delta E=100 \mathrm{mV})$. This potential is shifted by approximately $0.06 \mathrm{~V}$ to a more negative value, when compared with $\mathbf{3}$. This shifting confirms that the iron center in $\mathbf{6}$ is more easy to oxidize which is attributed to the electron donating properties of the $\mathrm{PdCl}$ units. [11]

ESI-TOF MS studies on $\mathbf{3 , 5}$ and $\mathbf{6}$ show in all cases the molecular ion $\mathrm{M}^{+}\left[\mathbf{3}, 567.2 \mathrm{~m} / \mathrm{z}\left(\mathrm{M}^{+}+\mathrm{H}\right) ; \mathbf{5}, 707.0\right.$ 
$\left.\mathrm{m} / \mathrm{z}\left(\mathrm{M}^{+}+\mathrm{H}\right) ; \mathbf{6}, 848.9 \mathrm{~m} / \mathrm{z}\left(\mathrm{M}^{+}+\mathrm{H}\right)\right]$. Further typical fragments for 5 and $\mathbf{6}$ are $\mathrm{M}^{+}-\mathrm{Cl}$ and $\mathrm{M}^{+}-\mathrm{Cl}+$ $\mathrm{MeCN}$. For 6 also $\mathrm{M}^{+}-\mathrm{PdCl}+\mathrm{H}$ and $\mathrm{M}^{+}-\mathrm{PdCl}_{2}+$ $\mathrm{H}$ are observed, while for $3(\mathrm{NCNH})_{2} \mathrm{H}^{+}$and $(\mathrm{NCNH}) \mathrm{C}_{6} \mathrm{H}_{3} \mathrm{CH}_{2} \mathrm{NMe}_{2}^{+}$are characteristic.

\section{Experimental}

\subsection{General methods}

All reactions were carried out under an atmosphere of purified nitrogen using standard Schlenk techniques. Tetrahydrofuran, diethyl ether and hexane were purified by distillation from sodium-benzophenone ketyl. $\mathrm{ZnCl}_{2}$ was dried with $\mathrm{SOCl}_{2} .{ }^{1} \mathrm{H}-\mathrm{NMR}$ spectra were recorded with a Varian Inova 300 spectrometer operating at $300.10 \mathrm{MHz}$ in the Fourier transform mode; ${ }^{13} \mathrm{C}\left\{{ }^{1} \mathrm{H}\right\}-$ NMR spectra were recorded at $75.47 \mathrm{MHz}$. Chemical shifts are reported in $\delta$ units (parts per million) downfield from tetramethylsilane with the solvent as the reference signal $\left(\mathrm{CDCl}_{3}:{ }^{1} \mathrm{H}-\mathrm{NMR}, \delta=7.26 ;{ }^{13} \mathrm{C}\left\{{ }^{1} \mathrm{H}\right\}\right.$ NMR, $\delta=77.0$ ). Cyclic voltammograms were recorded in a dried cell purged with purified nitrogen at $25^{\circ} \mathrm{C}$. Platinum wires served as working electrode and as counter electrode. A $\mathrm{Ag} / \mathrm{AgCl}$ electrode served as reference electrode. For ease of comparison, all electrode potentials are converted using the redox potential of the ferrocene-ferrocenium couple $\mathrm{Fc} / \mathrm{Fc}^{+}\left[\mathrm{Fc}=\left(\eta^{5}-\right.\right.$ $\left.\left.\mathrm{C}_{5} \mathrm{H}_{5}\right)_{2} \mathrm{Fe}\right]$ as the reference $(E=0.00 \mathrm{~V})$. Electrolyte solutions were prepared from fresh distilled acetonitrile and $\left[\mathrm{NBu}_{4}\right] \mathrm{PF}_{6}$ (dried in oil-pump vacuum at $120^{\circ} \mathrm{C}$ ). The respective organometallic complexes were added at $c=1 \mathrm{mM}$. CVs were recorded at a scan rate at $0.05 \mathrm{~V}$ $\mathrm{s}^{-1}$ using a Princeton Applied Research EG\&G 263A analyser.

Melting points were determined using sealed nitrogen purged capillaries on a Gallenkamp melting point apparatus. Microanalyses were performed by the Dornis und Kolbe, Mikroanalytisches Laboratorium, Mülheim a.d. Ruhr and by the Department of Organic Chemistry at Chemnitz Technical University. ESI-TOF mass spectra were recorded with a Mariner ESI-TOF mass spectrometer (Applied Biosystems) operating in the positive-ion mode in a acetonitrile solution.

\subsection{General remarks}

$\mathrm{Fe}\left(\eta^{5}-\mathrm{C}_{5} \mathrm{H}_{4} \mathrm{Li}\right)_{2} \cdot 2 / 3 \mathrm{TMEDA} \quad[12], \quad \mathrm{IC}_{6} \mathrm{H}_{3}\left(\mathrm{CH}_{2-}\right.$ $\left.\mathrm{NMe}_{2}\right)_{2}-3,5$ (2) [9] and $\left(\mathrm{Me}_{2} \mathrm{~S}\right)_{2} \mathrm{PdCl}_{2}$ [13] were prepared following published procedures. All other chemicals were purchased from commercial sources and were used without any further purification.

\subsubsection{Synthesis of $\mathrm{Fe}\left[\eta^{5}-\mathrm{C}_{5} \mathrm{H}_{4}(\mathrm{NCNH})\right]_{2}(3)$}

At $0{ }^{\circ} \mathrm{C}, 1.60 \mathrm{~g}(5.81 \mathrm{mmol})$ of $\mathrm{Fe}\left(\eta^{5}-\mathrm{C}_{5} \mathrm{H}_{4} \mathrm{Li}\right)_{2} \cdot 2 /$ 3TMEDA was dissolved in $100 \mathrm{ml}$ of tetrahydrofuran and $1.59 \mathrm{~g}(11.63 \mathrm{mmol})$ of $\mathrm{ZnCl}_{2}$ was added in one portion. After $1 \mathrm{~h}$ of stirring at this temperature a separately prepared solution of $\left[\mathrm{Pd}\left(\mathrm{PPh}_{3}\right)_{2}\right]$ [prepared by treatment of $204 \mathrm{mg}(0.29 \mathrm{mmol})$ of $\left(\mathrm{Ph}_{3} \mathrm{P}\right)_{2} \mathrm{PdCl}_{2}$ with $0.58 \mathrm{ml}(0.58 \mathrm{mmol})$ of diisobutylaluminiumhydride in $30 \mathrm{ml}$ of tetrahydrofuran] in $30 \mathrm{ml}$ of tetrahydrofuran was added. After additional $5 \mathrm{~min}$ of stirring, $1.85 \mathrm{~g}$ (5.81 mmol) of $\mathrm{IC}_{6} \mathrm{H}_{3}\left(\mathrm{CH}_{2} \mathrm{NMe}_{2}\right)_{2}-3,5$ (2), dissolved in $20 \mathrm{ml}$ of tetrahydrofuran, was added. The dark brown solution was allowed to warm to $25^{\circ} \mathrm{C}$. After stirring for 2 days, the reaction mixture was quenched with $50 \mathrm{ml}$ of $4 \mathrm{M} \mathrm{NaOH}$. The aqueous phase was separated and extracted with $50 \mathrm{ml}$ of chloroform. The combined organic phases were dried over $\mathrm{MgSO}_{4}$, filtered and evaporated in oil-pump vacuo. Chromatography over neutral alumina with diethyl ether gave $175 \mathrm{mg}(0.94$ mmol, $16 \%$ based on 2 ) of $\mathrm{Fe}\left(\eta^{5}-\mathrm{C}_{5} \mathrm{H}_{5}\right)_{2}$. By changing the solvent to diethyl ether-tetrahydrofuran (4:1 mixture) $\left(\eta^{5}-\mathrm{C}_{5} \mathrm{H}_{5}\right) \mathrm{Fe}\left[\eta^{5}-\mathrm{C}_{5} \mathrm{H}_{4}(\mathrm{NCNH})\right] \quad(778 \mathrm{mg}, \quad 36 \%$ based on 2) [14] could be obtained as a red oil. With methanol as eluent the title complex $3(643 \mathrm{mg}, 39 \%$ based on 2) could be isolated as a brown oil.

${ }^{1} \mathrm{H}-\mathrm{NMR}\left(\mathrm{CDCl}_{3}\right):[\delta] 2.25\left(\mathrm{~s}, 24 \mathrm{H}, \mathrm{NMe}_{2}\right), 3.40$ (s, $\left.8 \mathrm{H}, \mathrm{CH}_{2} \mathrm{~N}\right), 4.14\left(\mathrm{pt}, J_{\mathrm{HH}}=1.8 \mathrm{~Hz}, 4 \mathrm{H}, \mathrm{C}_{5} \mathrm{H}_{4}\right), 4.50(\mathrm{pt}$, $\left.J_{\mathrm{HH}}=1.8 \mathrm{~Hz}, 4 \mathrm{H}, \mathrm{C}_{5} \mathrm{H}_{4}\right), 7.06\left(\mathrm{~s}, 2 \mathrm{H}, \mathrm{C}_{6} \mathrm{H}_{3}\right), 7.21(\mathrm{~s}$, $\left.4 \mathrm{H}, \mathrm{C}_{6} \mathrm{H}_{3}\right) .{ }^{13} \mathrm{C}\left\{{ }^{1} \mathrm{H}\right\}-\mathrm{NMR}\left(\mathrm{CDCl}_{3}\right)$ : [ $\left.\delta\right] 45.4\left(\mathrm{NCH}_{3}\right)$, $64.4\left(\mathrm{NCH}_{2}\right), 68.0\left(\mathrm{CH}-\mathrm{C}_{5} \mathrm{H}_{4}\right), 70.8\left(\mathrm{CH}-\mathrm{C}_{5} \mathrm{H}_{4}\right), 85.9$ $\left({ }^{i} \mathrm{C}-\mathrm{C}_{5} \mathrm{H}_{4}\right), 125.7\left(\mathrm{CH}-\mathrm{C}_{6} \mathrm{H}_{3}\right), 127.7\left(\mathrm{CH}-\mathrm{C}_{6} \mathrm{H}_{3}\right), 138.4$ $\left({ }^{i} \mathrm{C}-\mathrm{C}_{6} \mathrm{H}_{3}\right), 138.6\left({ }^{i} \mathrm{C}-\mathrm{C}_{6} \mathrm{H}_{3}\right)$. ESI-TOF MS $[\mathrm{m} / z$ (rel. int.)] $567.2(100)\left[\mathrm{M}^{+}+\mathrm{H}\right], 383.2(20)\left[(\mathrm{NCNH})_{2} \mathrm{H}^{+}\right]$, 249.2 (10) [(NCNH) $\left.\mathrm{C}_{6} \mathrm{H}_{3} \mathrm{CH}_{2} \mathrm{NMe}_{2}^{+}\right]$. Anal. Calc. for $\mathrm{C}_{34} \mathrm{H}_{46} \mathrm{FeN}_{4}$ (566.59): C, 72.07; H, 8.18; N, 9.89. Found: C, 71.96; H, 8.09; N, 9.64\%.

\subsubsection{Synthesis of $\mathrm{Fe}\left[\eta^{5}-\mathrm{C}_{5} \mathrm{H}_{4}(\mathrm{NCNH})\right]\left[\eta^{5}-\right.$} $\left.\mathrm{C}_{5} \mathrm{H}_{4}(\mathrm{NCN}-\mathrm{PdCl})\right](5)$ and $\mathrm{Fe}\left[\eta^{5}-\mathrm{C}_{5} \mathrm{H}_{4}(\mathrm{NCN}-\right.$ $\mathrm{PdCl})]_{2}(6)$

${ }^{t} \operatorname{BuLi}(0.27 \mathrm{ml}, 0.41 \mathrm{mmol})(1.5 \mathrm{M}$ in hexane) was added to $103 \mathrm{mg}(0.18 \mathrm{mmol})$ of $\mathrm{Fe}\left[\eta^{5}-\mathrm{C}_{5} \mathrm{H}_{4}(\mathrm{NCNH})\right]_{2}$ (3), dissolved in $30 \mathrm{ml}$ of hexane, at $-80^{\circ} \mathrm{C}$. After stirring for $2 \mathrm{~h}$ and warming to $25^{\circ} \mathrm{C}$ all volatiles were removed in oil-pump vacuo. The light-brown residue was dissolved in $30 \mathrm{ml}$ of diethyl ether at $-20{ }^{\circ} \mathrm{C}$ and $109 \mathrm{mg}(0.36 \mathrm{mmol})$ of $\left(\mathrm{Me}_{2} \mathrm{~S}\right)_{2} \mathrm{PdCl}_{2}$ were added in one portion. The reaction mixture was stirred at $25^{\circ} \mathrm{C}$ over night and was evaporated. The dark brown residue was washed with hexane $(2 \times 5 \mathrm{ml})$, extracted with diethyl ether $(2 \times 30 \mathrm{ml})$ and then with dichloromethane $(2 \times 30$ $\mathrm{ml})$.

The combined diethyl ether extracts were evaporated in vacuo to afford $20 \mathrm{mg}(0.028 \mathrm{mmol}, 16 \%$ based on 3$)$ of $\mathrm{Fe}\left[\eta^{5}-\mathrm{C}_{5} \mathrm{H}_{4}(\mathrm{NCNH})\right]\left[\eta^{5}-\mathrm{C}_{5} \mathrm{H}_{4}(\mathrm{NCN}-\mathrm{PdCl})\right]$ (5) as orange solid. 
Compound 5: m.p. $84{ }^{\circ} \mathrm{C} .{ }^{1} \mathrm{H}-\mathrm{NMR}\left(\mathrm{CDCl}_{3}\right):[\delta] 2.28$ $\left(\mathrm{s}, 12 \mathrm{H}, \mathrm{NMe}_{2}\right), 2.95\left(\mathrm{~s}, 12 \mathrm{H}, \mathrm{NMe}_{2}\right), 3.45(\mathrm{~s}, 4 \mathrm{H}$, $\left.\mathrm{CH}_{2} \mathrm{~N}\right), 3.96\left(\mathrm{~s}, 4 \mathrm{H}, \mathrm{CH}_{2} \mathrm{~N}\right), 4.11\left(\mathrm{pt}, J_{\mathrm{HH}}=1.8 \mathrm{~Hz}, 2 \mathrm{H}\right.$, $\left.\mathrm{C}_{5} \mathrm{H}_{4}\right), 4.16\left(\mathrm{pt}, J_{\mathrm{HH}}=1.8 \mathrm{~Hz}, 2 \mathrm{H}, \mathrm{C}_{5} \mathrm{H}_{4}\right), 4.33(\mathrm{pt}$, $\left.J_{\mathrm{HH}}=1.8 \mathrm{~Hz}, 2 \mathrm{H}, \mathrm{C}_{5} \mathrm{H}_{4}\right), 4.52\left(\mathrm{pt}, J_{\mathrm{HH}}=1.8 \mathrm{~Hz}, 2 \mathrm{H}\right.$, $\left.\mathrm{C}_{5} \mathrm{H}_{4}\right), 6.76\left(\mathrm{~s}, 2 \mathrm{H}, \mathrm{C}_{6} \mathrm{H}_{2}\right), 7.08\left(\mathrm{~s}, 1 \mathrm{H}, \mathrm{C}_{6} \mathrm{H}_{3}\right), 7.26(\mathrm{~s}$, $\left.2 \mathrm{H}, \mathrm{C}_{6} \mathrm{H}_{3}\right) \cdot{ }^{13} \mathrm{C}\left\{{ }^{1} \mathrm{H}\right\}-\mathrm{NMR}\left(\mathrm{CDCl}_{3}\right):[\delta] 45.0\left(\mathrm{NCH}_{3}\right)$, $53.1\left(\mathrm{NCH}_{3}\right), 64.0\left(\mathrm{NCH}_{2}\right), 67.6\left(\mathrm{CH}-\mathrm{C}_{5} \mathrm{H}_{4}\right), 68.0$ $\left(\mathrm{CH}-\mathrm{C}_{5} \mathrm{H}_{4}\right), 70.6\left(\mathrm{CH}-\mathrm{C}_{5} \mathrm{H}_{4}\right), 70.9\left(\mathrm{CH}-\mathrm{C}_{5} \mathrm{H}_{4}\right), 74.7$ $\left(\mathrm{NCH}_{2}\right), 83.4\left({ }^{i} \mathrm{C}-\mathrm{C}_{5} \mathrm{H}_{4}\right), 85.1\left({ }^{i} \mathrm{C}-\mathrm{C}_{5} \mathrm{H}_{4}\right), 117.7(\mathrm{CH}-$ $\left.\mathrm{C}_{6} \mathrm{H}_{2}\right), 124.1\left(\mathrm{CH}-\mathrm{C}_{6} \mathrm{H}_{3}\right), 125.8\left(\mathrm{CH}-\mathrm{C}_{6} \mathrm{H}_{3}\right), 133.0$ $\left({ }^{i} \mathrm{C}-\mathrm{C}_{6} \mathrm{H}_{2}\right), 135.6\left({ }^{i} \mathrm{C}-\mathrm{C}_{6} \mathrm{H}_{3}\right), 137.1\left({ }^{i} \mathrm{C}-\mathrm{C}_{6} \mathrm{H}_{3}\right), 142.8$ $\left({ }^{i} \mathrm{C}-\mathrm{C}_{6} \mathrm{H}_{2}\right), 152.4\left({ }^{i} \mathrm{C}-\mathrm{C}_{6} \mathrm{H}_{2}\right)$. ESI-TOF MS $[\mathrm{m} / z$ (rel. int.)] $711.0(45)\left[\mathrm{M}^{+}-\mathrm{Cl}+\mathrm{MeCN}\right], 707.0(30)\left[\mathrm{M}^{+}+\right.$ $\mathrm{H}], \quad 671.0 \quad(100) \quad\left[\mathrm{M}^{+}-\mathrm{Cl}\right]$. Anal. Calc. for $\mathrm{C}_{34} \mathrm{H}_{45} \mathrm{ClFeN}_{4} \mathrm{Pd}$ (707.47): C, 57.72; H, 6.41; N, 7.92. Found: C, 56.84; H, 6.02; N, 7.36\%.

The combined dichloromethane extracts were evaporated in oil-pump vacuo to give $85 \mathrm{mg}(0.096 \mathrm{mmol}, 53 \%$ based on 2) of $\mathrm{Fe}\left[\eta^{5}-\mathrm{C}_{5} \mathrm{H}_{4}(\mathrm{NCN}-\mathrm{PdCl})\right]_{2}$ (6) as an orange powder.

Compound 6: m.p. $172{ }^{\circ} \mathrm{C}(\mathrm{dec}) .{ }^{1} \mathrm{H}-\mathrm{NMR}\left(\mathrm{CDCl}_{3}\right)$ : [ $\delta] 2.98\left(\mathrm{~s}, 24 \mathrm{H}, \mathrm{NMe}_{2}\right), 4.01\left(\mathrm{~s}, 8 \mathrm{H}, \mathrm{CH}_{2} \mathrm{~N}\right), 4.10$ (pt, $\left.J_{\mathrm{HH}}=1.8 \mathrm{~Hz}, 4 \mathrm{H}, \mathrm{C}_{5} \mathrm{H}_{4}\right), 4.39\left(\mathrm{pt}, J_{\mathrm{HH}}=1.8 \mathrm{~Hz}, 4 \mathrm{H}\right.$, $\left.\mathrm{C}_{5} \mathrm{H}_{4}\right), 6.80\left(\mathrm{~s}, 4 \mathrm{H}, \mathrm{C}_{6} \mathrm{H}_{2}\right) \cdot{ }^{13} \mathrm{C}\left\{{ }^{1} \mathrm{H}\right\}-\mathrm{NMR}\left(\mathrm{CDCl}_{3}\right):[\delta]$ $53.1\left(\mathrm{NCH}_{3}\right), 67.2\left(\mathrm{CH}-\mathrm{C}_{5} \mathrm{H}_{4}\right), 70.7\left(\mathrm{CH}-\mathrm{C}_{5} \mathrm{H}_{4}\right), 74.6$ $\left(\mathrm{NCH}_{2}\right), 86.8\left({ }^{i} \mathrm{C}-\mathrm{C}_{5} \mathrm{H}_{4}\right), 117.6\left(\mathrm{CH}-\mathrm{C}_{6} \mathrm{H}_{2}\right), 134.9\left({ }^{i} \mathrm{C}-\right.$ $\left.\mathrm{C}_{6} \mathrm{H}_{2}\right), 144.7\left({ }^{i} \mathrm{C}-\mathrm{C}_{6} \mathrm{H}_{2}\right), 154.4\left({ }^{i} \mathrm{C}-\mathrm{C}_{6} \mathrm{H}_{2}\right)$. ESI-TOF MS $\left[\mathrm{m} / z\right.$ (rel. int.)] 853.9 (30) $\left[\mathrm{M}^{+}-\mathrm{Cl}+\mathrm{MeCN}\right], 848.9$ (30) $\left[\mathrm{M}^{+}+\mathrm{H}^{+}\right], \quad 810.9 \quad(50) \quad\left[\mathrm{M}^{+}-\mathrm{Cl}\right], 707.0 \quad$ (25) $\left[\mathrm{M}^{+}-\mathrm{PdCl}+\mathrm{H}\right], 671.0(100)\left[\mathrm{M}^{+}-\mathrm{PdCl}_{2}+\mathrm{H}\right]$. Anal. Calc. for $\mathrm{C}_{34} \mathrm{H}_{44} \mathrm{Cl}_{2} \mathrm{FeN}_{4} \mathrm{Pd}_{2}$ (883.72): C, 48.14; $\mathrm{H}$, 5.23; N, 6.60. Found: C, 47.74; H, 5.53; N, 5.56\%.

\section{Acknowledgements}

We are grateful to the Deutsche Forschungsgemeinschaft, the Fonds der Chemischen Industrie and Utrecht University for financial support (research stay of S.K. in Utrecht). Dr. Bettina Lühmann is acknowledged for the measurement of the ESI-TOF mass spectra.

\section{References}

[1] (a) For example see: J.M. Longmire, X. Zhang, M. Shang, Organometallics 17 (1998) 4374;

(b) P. Dani, M. Albrecht, G.P.M. van Klink, G. van Koten, Organometallics 19 (2000) 4468;

(c) D.E. Bergbreiter, P.L. Osburn, Y. Liu, J. Am. Chem. Soc. 121 (1999) 9531;

(d) H.P. Dijkstra, P. Steenwinkel, D.M. Grove, M. Lutz, A.L. Spek, G. van Koten, Angew. Chem. Int. Ed. 38 (1999) 2186.

[2] (a) For example see: P. Steenwinkel, R.A. Gossage, G. van Koten, Chem. Eur. J. 4 (1998) 759;

(b) R.A. Gossage, L.A. van de Kuil, G. van Koten, Acc. Chem. Res. 31 (1998) 423;

(c) M. Albrecht, G. van Koten, Angew. Chem. Int. Ed. Engl. 40 (2001) 3750.

[3] G. Rodríguez, M. Albrecht, J. Schoenmaker, A. Ford, M. Lutz, A.L. Spek, G. van Koten, J. Am. Chem. Soc. 124 (2002) 5127.

[4] (a) S. Back, W. Frosch, I. del Rio, G. van Koten, H. Lang, Inorg. Chem. Commun. 2 (1999) 584;

(b) S. Back, M. Albrecht, A.L. Spek, G. Rheinwald, H. Lang, G. van Koten, Organometallics 20 (2001) 1024.

[5] (a) For examples see: F. Coat, C. Lapinte, Organometallics 15 (1996) 477;

(b) D. Astruc, Acc. Chem. Res. 30 (1997) 383;

(c) M. Brady, W. Weng, Y. Zhou, J.W. Seyler, A. Amoroso, A.M. Arif, M. Böhme, G. Frenking, J.A. Gladysz, J. Am. Chem. Soc. 119 (1997) 775.

[6] (a) T. Kaharu, H. Matsubara, S. Takahashi, J. Mater. Chem. 1 (1991) 145 ;

(b) A. Abe, N. Kimura, S. Tabata, Macromolecules 24 (1991) 6238.

[7] A. Suzuki, J. Organomet. Chem. 652 (2002) 83.

[8] (a) J.G.P. Delis, P.W.N.M. van Leeuwen, K. Vrieze, N. Veldman, A.L. Spek, J. Fraanje, K. Goubitz, J. Organomet. Chem. 514 (1996) 125;

(b) I.R. Butler, L.J. Hobson, S.J. Coles, M.B. Hursthouse, K.M. Abdul Malik, J. Organomet. Chem. 540 (1997) 27;

(c) M. Enders, G. Kohl, H. Pritzkow, J. Organomet. Chem. 622 (2001) 66.

[9] H.P. Dijkstra, M.D. Meijer, J. Patel, R. Kreiter, G.P.M. van Klink, M. Lutz, A.L. Spek, A.J. Canty, G. van Koten, Organometallics 20 (2001) 3157.

[10] K.R. Thomas, J.T. Lin, Y.S. Wen, J. Organomet. Chem. 575 (1999) 301

[11] N.J. Long, A.J. Martin, R. Vilar, A.J.P. White, D.J. Williams, M. Younus, Organometallics 18 (1999) 4261.

[12] J.J. Bishop, A. Davison, M.L. Katcher, D.W. Lichtenberg, R.E. Merrill, J.C. Smart, J. Organomet. Chem. 27 (1971) 241.

[13] P.K. Byers, A.J. Canty, H. Jin, D. Kruis, B.A. Markies, J. Boersma, G. van Koten, Inorg. Synth. 32 (1998) 162.

[14] S. Köcher, G.P.M. van Klink, G. van Koten, H. Lang, in press. 